\title{
BONE MINERAL DENSITY AND BODY COMPOSITION IN ELDERLY RUNNERS: SIX-YEAR FOLLOW-UP
}

\section{DENSIDADE MINERAL ÓSSEA E COMPOSIÇÃO CORPORAL DE IDOSOS CORREDORES: FOLLOW-UP DE SEIS ANOS}

\author{
Angelica Castilho alonso ${ }^{1,2,3}$, Rita de Cássia ERnandes ${ }^{2}$, Regina Helena Marques Pereira ${ }^{2}$, Ricardo André Becker ${ }^{1}$, \\ Adriana Machado-Lima ${ }^{1,2}$, Paulo Roberto Silva-Santos ${ }^{1,3}$, Julia Maria D'Andréa Greve ${ }^{1,3}$, Luiz Eugênio Garcez-Leme ${ }^{1,3}$ \\ 1. Universidade de São Paulo, Faculdade de Medicina, Hospital das Clinicas (HCFMUSP), Department of Orthopedics and Traumatology, Laboratory of Movement Studies, São Paulo, \\ SP, Brazil. \\ 2. Universidade São Judas Tadeu, Department of Postgraduate Studies in Aging Sciences, São Paulo, SP, Brazil. \\ 3. Universidade de São Paulo, Faculdade de Medicina, Hospital das Clinicas (HCFMUSP), Instituto de Ortopedia e Traumatologia, Orthogeriatric Group, São Paulo, SP, Brazil.
}

\section{ABSTRACT}

Objective: To evaluate bone mineral density (BMD) and body composition over a six-year period in elderly long-distance runners. Methods: We analyzed the medical records of elderly athletes who were long-distance runners, were participants of the IOT-HCFMUSP Orthogeriatric Group, and had their BMD evaluated between 2001 and 2007; of these athletes, 11 were included in the study. Inclusion criteria: athletes should be long-distance runners, should not stop long-distance running during the six-year period, and should have undergone BMD and body composition evaluations. Body composition was evaluated using bone densitometry with dual-energy $\mathrm{X}$-ray absorptiometry with a Lunar-DPX device. Results: Over the six-year period, body composition remained stable, but there was a significant increase only in the fat percentage $(p=0.003)$. Conclusion: Long-distance running may maintain BMD but may lead to an increase in the fat percentage in elderly runners. Level of Evidence II; Prognostic Study - Investigating the Effect of Patient Characteristics on Disease Outcome.

Keywords: Bone mineral density. Body composition. Running. Elderly.

\section{RESUMO}

Objetivo: Acompanhar a densidade mineral óssea (DMO) e a composição corporal, ao longo de seis anos, em idosos corredores de longa distância. Métodos: analisamos os prontuários médicos de um grupo de atletas idosos, corredores de longa distância, participantes do Grupo de Ortogeriatria do IOT-HC-FMUSP, e reunimos todos os atletas que tiveram a DMO avaliada no ano de 2001 e de 2007, sendo destes, 11 prontuários selecionados. Critérios de inclusão: ser corredor de longa distância; não parar de correr ao longo dos seis anos e ter os dois exames de DMO e composição corporal avaliados. A composição corporal foi avaliada por meio de densitometria óssea, com uma dupla energia de absorção de raios- $X$ (DEXA), em um aparelho LUNAR-DPX. Resultados: Ao longo dos seis anos, a composição corpórea se manteve estável, havendo apenas um aumento significante na gordura expressa em $(\%)(p=0,003)$. Conclusão: A corrida de longa distância parece conservar a DMO de idosos corredores, porém com aumento de gordura. Nível do Evidência Il; Estudos prognósticos - Investigação do efeito de características de um paciente sobre o desfecho da doença.

Descritores: Densidade mineral óssea. Composição corporal. Corrida. Idosos.

Citation: Alonso AC, Ernandes RC, Pereira RHM, Becker RA, do-Lima AM, Silva-Santos PR, Greve JMD, Garcez-Leme LE. Bone mineral density and body composition in elderly runners: six-year follow-up. Acta Ortop Bras. [online]. 2019;27(2):92-4. Available from URL: http://www.scielo.br/aob.

\section{INTRODUCTION}

Bone mass accumulation starts right from the fetal period and steadily increases through to pregnancy. Bone mineral density (BMD) is the result of a dynamic process for the formation and reabsorption of bone tissue, known as remodeling, which takes place throughout life in cycles, each four to six months in length. BMD maintenance is very important for the prevention of osteoporosis, which, together with other factors associated with age, could lead to a higher occurrence of fractures. Although bone loss is more evident and more intense in women, men also show some decrease in bone mass with age.1,2

Among the different courses of treatment, physical exercise is still considered the most efficient of the nonpharmacological strategies for the maintenance or increase of BMD. Bone tissue is positively affected by exercises promoting adaptations through stimuli, mainly mechanical, which contribute to bone formation. Therefore, exercise regimes including resistance and impact training are considered as the main nonpharmacological strategies for bone formation and maintanence. ${ }^{3}$

All authors declare no potential conflict of interest related to this article.

The study was conducted at the Universidade de São Paulo, Faculdade de Medicina, Hospital das Clinicas (HCFMUSP), Department of Orthopedics and Traumatology, Laboratory of Movement Studies, São Paulo, in association with Universidade São Judas Tadeu, Department of Postgraduate Studies in Ageing Sciences, São Paulo, Brazil. Correspondence: Angelica Castilho Alonso, Rua Ovídio Pires de Campos, 333, Cerqueira César, São Paulo, SP 01246-000, Brazil. angelicacastilho@msn.com 
As BMD is a measure of bone mineral status, it can also be influenced by various factors such as body composition, ${ }^{3}$ genetics, hormonal state, exposure to sunlight, eating habits, and lifestyle. $\mathrm{BMD}$ is also closely associated with sport practice, which plays an important role in the development and maintenance of lean and bone mass. ${ }^{4,5}$

In adult athletes, there is evidence that BMD is associated with sport practice during teenage years, and long-term training could lead to an increase in BMD. ${ }^{6}$

The effects of sport practice on BMD vary depending on the sport practiced and the intensity of the impact. ${ }^{7}$ Activities with body overload have the ability to boost the increment in bone mass, as the skeleton self-organizes itself according to the load coming from the specific sport. The involvement of different segments of the body also helps to increase BMD values. ${ }^{7}$

Therefore, the purpose of this study was to evaluate BMD and body composition over a six-year period in elderly long-distance runners.

\section{MATERIALS AND METHODS}

This was a cohort study conducted over a six-year period and was developed by the Orthogeriatric Group at IOT-HCFMUSP (CAPesq no. 1167/06) in association with Universidade São Judas Tadeu.

\section{Sample}

We analyzed the medical records of elderly athletes who were long-distance runners, were participants of the Orthogeriatric Group of IOT-HCFMUSP, and had undergone BMD evaluation between 2001 and 2007; of these athletes, 11 were selected. The inclusion criteria were that the participants should be long-distance runners, should not stop long-distance running during the six-year period, and should have undergone BMD and body composition evaluations performed by the same physician by using the same machine in the Radiology Department of the IOT.

\section{Evaluation of BMD and Body Composition}

Body composition was evaluated using bone densitometry with dual-energy X-ray absorptiometry with a LUNAR-DPX device (Madison Corporation, USA) by trained professionals.

\section{Statistical Analysis}

Data were analyzed using SPSS 20 software and presented using means and standard deviations. The Shapiro-Wilk test was used to determine whether the continuous quantitative variables were normally distributed. The paired $t$-test was used to compare dependent samples. Statistical significance was set at $5 \%$.

\section{RESULTS}

Over the six-year study period, the subjects maintained the same volume of training, and there was a significant difference only in their age and years of experience (Table 1).

Moreover, BMD was maintained in the subjects (Figure 1 and Table 2), and no statistically significant differences were observed in BMD.

Table 1. Age, running experience, and training volume of elderly long-distance runners over a six-year follow-up period.

\begin{tabular}{c|c|c|c}
\hline & $\mathbf{2 0 0 1}$ & $\mathbf{2 0 0 7}$ & $\mathbf{p}$ \\
\hline Age (years) & $65.5(5.2)$ & $71.5(4.9)$ & $\leq 0.001^{*}$ \\
\hline Frequency/week (days) & $4.2(0.9)$ & $4.0(0.7)$ & 0.465 \\
\hline $\mathrm{km} /$ day & $9.9(1.2)$ & $9.3(1.6)$ & 0.258 \\
\hline $\mathrm{km} /$ week & $43.3(14.1)$ & $38.0(11.3)$ & 0.322 \\
\hline Experience (years) & $17.1(4.3)$ & $23.1(4.0)$ & $\leq 0.001^{*}$ \\
\hline
\end{tabular}

Paired $t$-test. $p \leq 0.05^{\star}$. km - kilometers.
In addition, body composition remained constant, but there was a significant increase in only the fat percentage in the subjects (Table 2). In 2001, there was no correlation between the number of training sessions per week and BMD; however, in 2007, there was a significantly positive correlation between the two variables, suggesting that BMD increased when the weekly training load increased. (Figure 2)

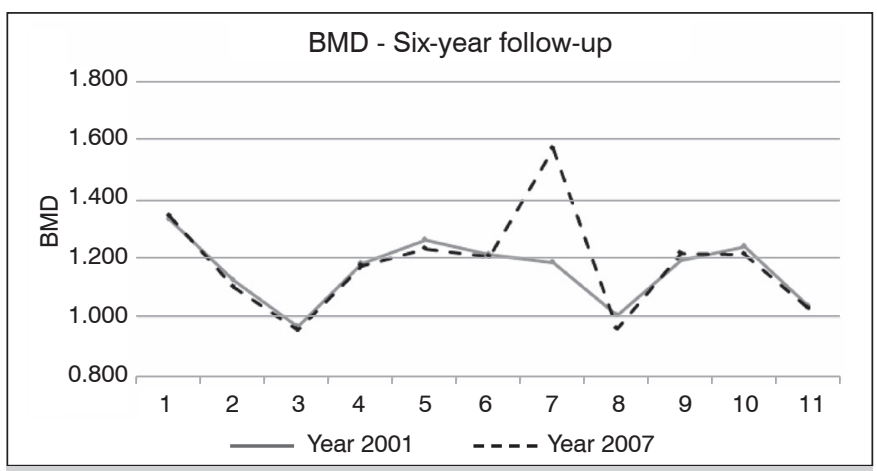

Figure 1. A six-year follow-up of bone mineral density (BMD) levels in elderly long-distance runners.

Table 2. Bone mineral density and body composition in elderly long-distance runners over a six-year follow-up period.

\begin{tabular}{c|c|c|c}
\hline & $\mathbf{2 0 0 1}$ & $\mathbf{2 0 0 7}$ & $\mathbf{p}$ \\
\hline BMD & $1.15(0.1)$ & $1.18(0.1)$ & 0.536 \\
\hline Fat $(\%)$ & $16.7(5.7)$ & $19.0(4.5)$ & $0.003^{*}$ \\
\hline Tissue (g) & $60762.9(5087.7)$ & $56317.7(16729.3)$ & 0.390 \\
\hline Fat (g) & $10255.1(4017.0)$ & $10684.2(4357.6)$ & 0.756 \\
\hline Lean (g) & $50507.8(4268.9)$ & $45633.5(13637.2)$ & 0.209 \\
\hline BMC (g) & $2709.0(408.9)$ & $2462.1(748.6)$ & 0.206 \\
\hline Total Calcium & $1029.0(155.3)$ & $934.9(284.5)$ & 0.204 \\
\hline
\end{tabular}

Paired $t$-test. $p \leq 0.05^{\star}$. BMD - bone mineral density; $g$ - grams; BMC - bone mineral content.
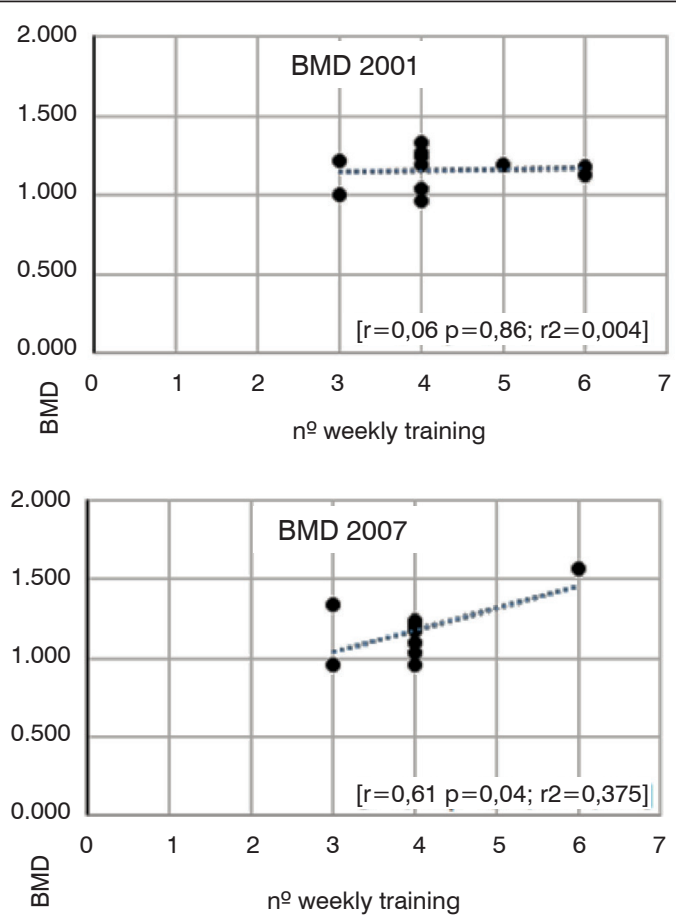

Figure 2. Correlation between bone mineral density (BMD) and the number of weekly training sessions between 2001 and 2007 in elderly long-distance runners. 


\section{DISCUSSION}

The main finding in the present study was that in elderly long-distance runners, BMD and body composition were maintained, but the fat percentage increased over a six-year period. This suggests that long-distance running seems to have a positive effect on the maintenance of these variables, and it is necessary to increase the stimulus in order to increase BMD.

$\mathrm{BMD}$ is reported to decrease with age, ${ }^{3}$ but in the present study, BMD remained stable, showing just a slight nonsignificant increase over a six-year period. Moreover, none of the athletes showed any signs of osteopenia or osteoporosis in a study by Nowak et al., ${ }^{8}$ comparing male long-distance runners and male nonathletes. Further, sport practice induced beneficial effects and helped maintain BMD. ${ }^{9}$ Bone mass may be maintained and its decrease may be prevented in athletes who participate in endurance activities such as middle-distance and long-distance running and undergo training for long periods, ${ }^{10}$ because the distribution of plantar pressure occurs through a "mata-borrão" movement, in which the body weight of the athlete travels across the entire foot, from the heel to the tips of the toes. ${ }^{11}$ It should be considered that athletes and people who engage in physical exercise have better bone mass than those who do not engage in physical exercise; this is owing to the mechanical overload on the bone, inducing the formation of osteoblasts, piezoelectric effect, and the same mechanism of traction of the muscles on the bone. ${ }^{3}$ However, studies have shown that after a certain BMD peak is reached, there is no further improvement in bone mineralization unless there is an increase and modification of the stimulus. ${ }^{12}$ Indeed, results of the present study show that only an increase in the stimulus leads to an improvement of BMD. In contrast, cessation of training leads to worsening of the quantity and quality of bone tissue. ${ }^{13}$ With regard to body composition, we observed an increase in the fat percentage, which is in line with the findings reported by Alonso et al., ${ }^{14}$ who affirmed that body composition changes significantly in elderly individuals, including the increase and redistribution of adipose tissue. This distribution increases progressively within the abdominal cavity and is less pronounced in the limbs.

In the present study, despite the significant increase in the fat percentage over the six-year period, the athletes had low body weight, characteristic of long-distance runners, and the fat percentage was a borderline value of the normal range. In a study performed by Prouteau et al., ${ }^{15}$ low body weight and weight loss were associated with a low BMD level, caused by a decrease in the mechanical load on the skeleton; ${ }^{16,17}$ compared to men with a sedentary lifestyle, runners and cyclists were reported to have a fairly low body weight and inconsistent BMD levels. ${ }^{18}$ In the present study, we evaluated the subjects from a gerontological perspective over a six-year period. These elderly athletes may have a reduced risk of osteopenia and osteoporosis because of their healthy lifestyle. 19,20

The main contribution of this study is related to understanding the applicability of exercises to BMD. Long-distance running is a good activity for maintaining bone mass; however, it is necessary to increase the stimulus in order to improve BMD.

\section{CONCLUSION}

Long-distance running may maintain BMD but may lead to an increase in the fat percentage in elderly runners.

AUTHORS' CONTRIBUTIONS: Each author made significant individual contributions to this study. ACA (0000-0002-9644-5068* was the lead author who analyzed the study data and prepared the manuscript; RCE (0000-0003-2272-5320* assisted in preparing the manuscript; RAB (0000-0003-3530-3995)* assisted in preparing the manuscript; AML (0000-0002-5741-3418)* assisted in preparing the manuscript; PRSS (0000-0003-1223-5862)* assisted in preparing the manuscript and collecting data; JMDAG (0000-0003-1778-0448** made the final corrections to the manuscript; LEGL (0000-0002-9738-5466)* was responsible for requesting, collecting, and analyzing the examination results and making the final corrections to the manuscript; RHMP (0000-0002-98960493)* prepared the references and was responsible for manuscript submission. All authors approved the final version of the manuscript. *ORCID (Open Researcher and Contributor ID).

\section{REFERENCES}

1. Burt LA, Naughton GA, Greene DA, Courteix D, Ducher G. Non-elite gymnastics participation is associated with greater bone strength, muscle size, and function in pre- and early pubertal girls. Osteoporos Int. 2012;23(4):1277-86.

2. Maïmoun L, Sultan C. Effects of physical activity on bone remodeling. Metabolism. 2011;60(3):373-88

3. Aboarrage Junior AM, Teixeira CVLE, Santos RN, Machado AF, Evangelista AL, Rica RL, et al. A high-intensity jump-based aquatic exercise program improves bone mineral density and functional fitness in postmenopausal women. Rejuvenation Res. 2018 Dec;21(6):535-540. doi: 10.1089/rej.2018.2069. Epub 2018 Nov 28.

4. Maïmoun L, Lumbroso S, Manetta J, Paris F, Leroux JL, Sultan C. Testosterone is significantly reduced in endurance athletes without impact on bone mineral density. Horm Res. 2003;59(6):285-92.

5. Alwis G, Linden C, Ahlborg HG, Dencker M, Gardsell P, Karlsson MK. A 2-year school-based exercise programme in pre-pubertal boys induces skeletal benefits in lumbar spine. Acta Paediatr. 2008;97(11):1564-71

6. Rantalainen T, Weeks BK, Nogueira RC, Beck BR. Effects of bone-specific physical activity, gender and maturity on tibial cross-sectional bone material distribution: A cross-sectional pQCT comparison of children and young adults aged 5-29years. Bone. 2015;72:101-8.

7. Ubago-Guisado E, Gómez-Cabello A, Sánchez-Sánchez J, García-Unanue $\mathrm{J}$, Gallardo L. Influence of different sports on bone mass in growing girls. J Sports Sci. 2015;33(16):1710-8.

8. Nowak A, Hubbard RE. Falls and frailty: Lessons from complex systems. J R Soc Med. 2009;102(3):98-102.

9. Mackelvie KJ, Taunton JE, Mckay HA, Khan KM. Bone mineral density and serum testosterone in chronically trained, high mileage 40 - 55 year old male runners. Br J Sports Med. 2000;34(4):273-8.

10. Feldman S, Capozza RF, Mortarino PA, Reina PS, Ferretti JL, Rittweger J, et al. Site and sex effects on tibia structure in distance runners and untrained people.
Med Sci Sports Exerc. 2012;44(8):1580-8.

11. Borin JP, Rodrigues A, Dallemole C, Ferreira CKO, Donato F, Leite GS, et al. Buscando Entender a Preparação Desportiva a Longo Prazo a Partir Das Capacidades Físicas Em Crianças. Arq em Mov. 2007;3(1):87-102.

12. Karlsson KM, Karlsson C, Ahlborg HG, Valdimarsson Ö, Ljunghall S. The Duration of Exercise as a Regulator of Bone Turnover. Calcif Tissue Int. 2003;73(4):350-5.

13. Lehtonen-Veromaa M, Möttönen T, Kautiainen $\mathrm{H}$, Heinonen OJ, Viikari J. Influence of physical activity and cessation of training on calcaneal quantitative ultrasound measurements in peripubertal girls: A 1-year prospective study. Calcif Tissue Int. 2001;68(3):146-50

14. Alonso AC, Gonçalves A, Alves De Almeida JK, Machado-Lima A, Ernandes RC, Greve JMD, et al. Relationship Between Bone Mineral Density and Body Composition in Elderly. Acta ortop bras. 2018;26(1):2017-9.

15. Prouteau S, Benhamou L, Courteix D. Relationships between serum leptin and bone markers during stable weight, weight reduction and weight regain in male and female judoists. Eur J Endocrinol. 2006;154(3):389-95.

16. Zanker CL, Swaine IL. Responses of bone turnover markers to repeated endurance running in humans under conditions of energy balance or energy restriction. Eur J Appl Physiol. 2000;83(4-5):434-40.

17. Ihle R, Loucks AB. Dose-response relationships between energy availability and bone turnover in young exercising women. J Bone Miner Res. 2004;19(8):1231-40.

18. Nichols JF, Palmer JE, Levy SS. Low bone mineral density in highly trained male master cyclists. Osteoporos Int. 2003;14(8):644-9.

19. Lazarus NR, Harridge SDR. Exercise, physiological function, and the selection of participants for aging research. J Gerontol A Biol Sci Med Sci. 2010;65(8):854-7.

20. Michaëlsson K, Olofsson H, Jensevik K, Larsson S, Mallmin H, Berglund L, et al. Leisure physical activity and the risk of fracture in men. PLoS Med. 2007;4(6):1094-100. 